\title{
Research into the "Internet+Education" Technology Flipped Classroom English Teaching Mode
}

\author{
Lei Liu \\ Qiqihaer medical university, Shandong province, 161006, China \\ liulei_2008@163.com
}

Keywords: Internet; Education; Flipped classroom; English teaching

\begin{abstract}
At both middle schools and colleges, polarization among students exists in English education. Therefore, flipped classroom is needed to reduce such polarization and teachers' load, improve students' independent learning ability and finally reduce unfairness in English education. Meanwhile, "Internet + education" technology flipped classroom teaching mode can conform to the rules for learners to construct knowledge. Besides, flipped classroom is being reformed in many aspects while relying on multimedia network technology to better extend classroom teaching, and learners can have more enthusiasm, greatly expand their knowledge and finally, their appreciation ability and learning ability are improved. Thus, flipped classroom can bring students a happy and full English learning process.
\end{abstract}

\section{Introduction}

With the development and changes of multimedia network technology, people can have more communication through the Internet, and to apply Internet in the education field can bring huge development opportunity for education. Flipped classroom can bring true changes to English classroom teaching by taking students as the focus and making students understand the importance of their learned knowledge, so students' ability can be really improved. The Internet technology makes English learning become richer and more colorful and greatly extends English learning. The emergence of flipped classroom embodies a strong technical support, and reform of flipped English classroom can more traditional teaching more active and motivated, which greatly changes students' present learning situation and gives students more positive and powerful improvement.

\section{Features and Advantages of Flipped Classroom Teaching}

Features of Flipped Classroom Teaching Flipped classroom, also called converted classroom, comes from Woodland Park High School in the Rocky Mountains, Colorado, the United States. Such flipped classroom is to use the Internet technology to change traditional teaching. Reformed teaching is completed after class, and students' English homework and practical operation process is converted from after class to the class through collaboration with teachers and discussion with students. Thus, the traditional teaching is entirely changes, and features of the typical Internet + education technology flipped classroom teaching have the several following features:

Conversion of Teachers and Students' Roles. In traditional teaching, teachers are the leaders as well as knowledge transmitter while students can only passively accept the knowledge. In the Internet + education technology flipped classroom teaching, teachers will withdraw from the key of teaching, so that they can better guide, assist and evaluate students. Teachers provide scientific learning scripts for students to create a different learning atmosphere for students so that students become the center of the learning process. Only when students are get involved in knowledge impartment can they internalize English knowledge.

Changes of Teaching Procedures. The Internet + education technology flipped classroom mode completely changes the traditional teaching procedures as the teacher-dominated classroom teaching mode is converted to the mode in which students learn extracurricular knowledge with the aid of multimedia network technology. Such changes of teaching procedures gradually change students' learning status and make students subordinate status changed to the main status. 
Reconstruction of Knowledge Construction Ways. The Internet + education technology flipped classroom teaching mode provides students with a more reasonable recognition process while learning knowledge. Traditional English teaching is a cramming teaching mode, in which students are at a passive status, and in this mode, students cannot become really active in learning English, and it cannot reflect students' real recognition path. Flipped classroom truly motivates students' enthusiasm in learning English, so that students become more active in learning and the process of their self-cognition becomes more standardized and in full compliance with the laws of cognition.

Advantages of Flipped Classroom. In flipped classroom teaching, students can master the course process on their own and arrange and control their learning process with the aid of online teaching video and according to their actual situation. In the process of learning English, if they omit some knowledge, it will result in a chain effect and bad performance in English. After watching students' video after class or at home, students can learn with a relaxed mind instead of being nervous in classroom teaching or falling behind others due to their poor ability. Students can also fast forward online video and repeatedly watch the parts they cannot understand. Meanwhile, they can stop to take notes or think or seek help from teachers through QQ. Therefore, flipped classroom teaching with the aid of the Internet + education technology can better help students in learning, so as to solve the problem regarding distance to a greater extent. Teachers can completely master students' extracurricular life, which can help students to timely supervise students. Moreover, this teaching mode narrows the link between schools and parents to a large extent and can provide more convenience and help for students in learning English.

\section{Traditional English Teaching Mode and "Internet + Education Technology" Flipped Classroom English Teaching Mode}

Traditional English Teaching Mode. As an important subject, English plays a significance role in students' future study, work and life. Many English teaching rules stipulate that the task of English teachers is to cultivate students' comprehensive skills, such as reading and comprehension ability, grammar and rhetoric and writing skills. However, there are various difficulties for students to read English articles, such as wide genres, complex contents, rich rhetoric and limited teaching hours, so English teachers are faced with more difficulties. Therefore, in such complex and difficult environment, teachers occupy the dominant position in the classroom while students are passive to take notes. Such mode can make teachers more tired and students cannot cultivate their interest in learning or improve their practical English ability. Thus, students cannot improve their learning ability, which is unfavorable for students' future study, work and life.

"Internet + Education Technology" Flipped Classroom English Teaching Mode. Some people think that knowledge is people's interpretation, assumptions and hypothesis of the objective world, but scholars have different understanding of knowledge. They have their unique understanding. Each learner can understand knowledge according to their own experience and background, and special learning environment and situations are mutually connected. "Internet + Education Technology" is to provide students with an environment to construct knowledge according to their backgrounds. Traditional English teaching mode does not pay much attention to individual learners' demand for constructing knowledge environment, while "Internet + education technology" flipped classroom brings new vitality to English teaching. In recent years, a lot of educators reconstruct their own teaching design according to this concept so as to closely connect English teaching with flipped classroom. The following is to reconstruct the learning environment of English teaching before class, at class and after class.

Reconstruction of Learning Environment before Class. Multimedia network technology has provided English teaching with a sufficient communication platform and become the link for communication between teachers and students. Teachers carefully design the learning task of each text through flipped classroom and the convey it to individual students so that students can better complete the learning targets, contents, methods and effect test, etc. Meanwhile, teachers seek some knowledge resources in conformity with the taught contents through the Internet, such as texts, 
pictures and videos, etc. Besides, "Internet + education technology" flipped classroom can design reasonable and effect questions and exercises for the texts, bring teachers and students better knowledge preparation before learning, help students solve more practical English problems through group discussions so as to better complete individuals' knowledge construction.

Construction of Classroom Teaching Interactive Environment. After teachers collect the results of group discussion before English class, those valuable problems become the guide of the class so as to help students solve some problems that they cannot solve on their own through interaction with teachers and cooperation with other students at class. The construction of an interactive environment must be guided by cultivating students' independent learning ability, so students' independence of learning English should be respected, their thinking should be improved through communication and discussion so that students can have their innovative thinking. Besides, a relaxing and interactive teaching environment should be created to make students better construct knowledge, so that unfavorable learning factors can be solved.

After-Class Learning Reflection. Teachers end their design of learning tasks does not mean students can learn English knowledge well, so students must reflect so as to further enhance their learning. Because through reflection, students can find loopholes in learning and better learn and understand new knowledge. Also, through reflection, students can think independently, which can cultivate their learning ability, so after completing their own teaching tasks, teachers also need to know more about students' reflection, collect some reflection questions to give better answers to students so that students can better reflect, which will finally lead students to develop towards a better learning direction. "Internet + education technology" flipped classroom English teaching mode has achieved certain remarkable achievements in massive English classes. First of all, the establishment of online communication platform can better help students to frequently communicate with teachers and their classmates, which can motivate students' more interest and enthusiasm in learning. Meanwhile, to develop network resources can bring more support and promotion to students' learning efficiency, so that they cannot only get learning materials from teachers, but also search their learning contents from the Internet, which greatly expands their horizons and makes them better recognize the society and life. In addition, it can arouse students' interest and aspiration in research, laying a good foundation for their future English ability. After all, students' English learning must be associated with reflection so as to bring more unique English learning effect.

\section{Problems in "Internet + Education Technology" Flipped Classroom English Teaching}

English Teachers and Students" Understanding of "Internet + Education Technology" Flipped Classroom is not Profound. For English teachers and students, they will have a natural response to traditional English teaching and incorrect understanding of "Internet + education" flipped classroom English teaching because flipped classroom has just entered the regulation of English teaching, teachers and students cannot have a clear understanding of "Internet + education technology" flipped classroom, so that they cannot better use and accept flipped classroom, nor well analyze and utilize flipped classroom, thus they finally enter and passive status, posing certain difficulties to "Internet + education technology" flipped classroom English teaching.

Some English Teachers and Students are Over Dependent on "Internet + Education Technology" Flipped Classroom As "Internet + education technology" flipped classroom is gradually integrated into English teaching, some teachers and students may become over dependent on such mode, and such excessive dependence can make English teachers completely abandon their education and guidance on students, and students will become excessively obsesses by interesting parts in the Internet while neglecting the importance of English learning but regarding the Internet as a game instead of putting the focus of work on real study. Students and teachers' over dependence on "Internet + education technology" flipped classroom can make English teaching and learning ineffective, thus affecting the teaching and study effect.

Teachers and Students Cannot Innovate "Internet + Education Technology" Flipped Classroom Mode in English Teaching and Study In recent years, "Internet + education 
technology" flipped classroom teaching mode is widely applied in schools, and English teaching and learning cannot be separated from such mode. However, in actual English teaching, teachers and students cannot better understand flipped classroom mode nor innovate flipped classroom, but they arrange "Internet + education technology" flipped classroom mode passively. Such mode of teaching and learning can make teachers and students not understand the knowledge nor utilize it, which becomes a setback. Finally, English teaching and study goes to a dead end.

\section{Countermeasures in "Internet + Education Technology" Flipped Classroom English Teaching}

Enhance Promotion of Flipped Classroom to Make Teachers and Students Better Understand Flipped Classroom Enhance promotion of "Internet + education technology" flipped classroom to make flipped classroom better serve for teachers and students, teachers and students can better realize the role of flipped classroom and understand the importance. Only when flipped classroom goes deep into teachers and students can it be associated with English and better promote teachers' teaching and benefit students in learning English. Teachers and students need to better understand flipped classroom, and only in this way can teachers and students have more motivation in teaching and study, which will bring teachers and students more help, guide teachers to have successful teaching and students learn better.

Flipped Classroom Should be Better Utilized to Make them become Guider and User of Flipped Classroom Teachers and students should not become excessively dependent on "Internet + education technology" flipped classroom. They should understand the relation between flipped classroom and themselves, better utilize flipped classroom, become the guide and user of it and learn to reasonably use "Internet + education technology" flipped classroom and insert such mode reasonably in classes to make it a fixed mode instead of a dependence. Flipped classroom should be better used to better serve teachers and students, making teachers improve their teaching ability and students improve their learning performance.

Integrate Innovative Elements in "Internet+ Education Technology" Flipped Classroom "Internet + education technology" flipped classroom is a new teaching mode, and English teaching should rely on such mode for teaching and study. However, at present, teachers and students only carry out teaching and study according to a fixed mode without adding new elements, so teachers and students should flexibly use such mode and add innovative elements in it. For example, teachers can allow students to choose video and teaching ways and make them become the guide of "Internet + education technology" flipped classroom. Teachers can join English study as students so as to better interpret flipped classroom and finally better use "Internet + education technology" flipped classroom.

\section{Conclusion}

This paper introduces the features and advantages of flipped classroom and compares traditional English teaching mode and "Internet + education technology" flipped classroom English teaching mode. Then, it proposes problems in "Internet + education technology" flipped classroom English teaching. For example, teachers and students do not have a profound understanding of "Internet + education technology" flipped classroom, some teachers and students are over dependent on "Internet + education technology" flipped classroom, etc. Finally, this paper puts forward some corresponding measures to better apply "Internet + education technology" flipped classroom so as to better help English teaching and study.

\section{Acknowledgements}

Found:EMP Teaching Research in Medical Colleges Depending on the Professional Requirements in the Environment of Flipped Classroom(0315008) 


\section{References:}

[1] L.Lan. Empirical Research into High School English Writing Teaching Design based on Flipped Classroom (MS Harbin Normal University 2016). p.48.

[2] S.M. Liao. Construction of College English Flipped Classroom Teaching Mode against the "Internet + Education" Background [J].Journal of Jiamusi Occupational, (2016) No.7, p.360-363.

[3] C.X. Li. Research into English Flipped Classroom Teaching Mode against the "Internet + Education" Background [J] China Training, (2016), No.303, p.45, 48.

[4] N.Ni. Research into Application of Flipped Classroom in Rural Primary School English Teaching - Take an Example of a Primary School in Baoding (MS Yangzhou University 2015). p.25.

[5] X.Y. Zhou. Research and Practice of English Flipped Classroom Teaching Mode at Junior Colleges against the "Internet + Education" Background [J] Journal of Hunan University of Science and Technology, Vol. 37 (2016) No.12, p.140-141.

[6] H.Qiu. Research into College English Teaching based on Flipped Classroom Teaching Mode Take an Example of Chinese Culture Course (Northeast Petroleum University 2014). p. 20. 